\title{
Tinjauan Yuridis Illegal Fishing di Indonesia Berdasarkan Undang-Undang Perikanan
}

\author{
Oleh: Inggrit Fernandes* \\ Dosen Hukum Internasional Univeritas Islam Indragiri \\ Jalan Stadion. No. 130 Tembilahan Riau
}

\begin{abstract}
Abstrak
Tujuan penelitian ini untuk menjelaskan tinjauan yuridis illegal fishing di Indonesia dan menjelaskan sanksi terhadap illegal fishing di Indonesia. Metode penelitian yang digunakan penelitian hukum normatif dengan metode pendekatan yuridis normatif. Hasil penelitian tinjauan yuridis illegal fishing definisinya tidak ada dicantumkan dalam peraturan perundang-undangan terkait perikanan. Tetapi, peraturan perundang-undangan tersebut jika dilanggar dapat dikategorikan illegal fishing. Peraturan perundangundangan perikanan secara tegas harus ditegakkan dalam rangka menjaga kedaulatan wilayah perairan. Setiap orang, badan dan negara asing wajib tunduk pada ketentuan hukum agar tidak terkena sanksi illegal fishing. Untuk memanfaatkan sumber daya perikanan agar tidak terkena sanksi illegal fishing maka dalam keadaan tertentu mesti dilengkapi persyaratan perizinan. Sanksi terhadap illegal fishing diatur dalam Undang-Undang Perikanan terdapat dalam beberapa pasal diantaranya Pasal 84 sampai dengan Pasal 104. Berbagai upaya telah dilakukan oleh Pemerintah dalam rangka pencegahan dan penindakan illegal fishing selanjutnya sangat diperlukan kerjasama dan koordinasi diantara seluruh unsur terkait sehingga dapat mengamankan dan melindungi sumber daya alam untuk kepentingan nasional. Simpulan penelitian ini: Pertama, Undang-Undang Perikanan telah merumuskan banyak hal baik mengenai pencegahan, pengawasan, pemberdayaan dan penindakan terhadap pelaku sektor perikanan baik nelayan nasional maupun nelayan asing. Kedua, sanksi dalam Undang-Undang Perikanan terbaru lebih berat dibandingkan undang-undang sebelumnya. Dengan sanksi
\end{abstract}

*Penulis korespondensi e-mail: inggrit_f@yahoo.com 
yang lebih beratpun belum memberikan efek jera kepada pelaku illegal fishing.

Kata Kunci: Perikanan, Illegal, Fishing.

\begin{abstract}
The purpose of this study is to explain the juridical review of illegal fishing in Indonesia and explain the sanctions against illegal fishing in Indonesia. The research method used normative legal research with normative juridical approach method. The results of the juridical review of illegal fishing definition are not included in the legislation related to fisheries. However, the legislation if violated can be categorized as illegal fishing. The laws and regulations of fisheries should be strictly enforced in order to maintain the sovereignty of the territorial waters. Every person, body and foreign country shall be subject to legal provisions in order not to be subject to illegal fishing sanctions. To utilize fishery resources in order not to get sanctioned illegal fishing then in certain circumstances must be equipped with permit requirements. Sanctions against illegal fishing regulated in the Fisheries Act are contained in several articles such as Article 84 to Article 104. Various efforts have been made by the Government in order to prevent and repel illegal fishing then it is necessary cooperation and coordination among all related elements so as to secure and protect natural resources for the national interest. Conclusions of this research: First, the Fisheries Law has formulated many good things about prevention, supervision, empowerment and action against fishery sector actors, both national fishermen and foreign fishermen. Secondly, sanctions in the latest Fisheries Act are heavier than previous laws. With sanctions that are not even heavy give a deterrent effect to the perpetrators of illegal fishing.
\end{abstract}

\title{
Keywords: Fishery, Illegal, Fishing.
}




\section{Pendahuluan}

Indonesia negara kepulauan terbesar di dunia, yang mencakup 17,508 pulau (citra satelit terakhir menunjukkan 18,108 pulau), sebanyak 6.000 diantaranya berpenduduk. Wilayah Indonesia yang terbentang dan $6^{\circ} 08^{\prime}$ Lintang Utara hingga $11^{\circ} 15^{\prime}$ Lintang Selatan, dan dan 94045 Bujur Timur hingga $141^{\circ} 05^{\prime}$ Bujur Timur terletak di posisi geografis sangat strategis, karena menjadi penghubung dua samudera dan dua benua, Samudera India dengan Samudera Pasifik, dan Benua Asia dengan Benua Australia.

Sebagai negara kepulauan sebagian besar wilayah Indonesia terdiri dan laut, memiliki potensi perikanan yang sangat berperan memperkuat sektor ekonomi. Hal mi dapat menjadi aset pembangunan Indonesia. Sebagaimana termaktud dalam Pasal 33 ayat (3) Undanglindang Dasar (UUD) 1945 "Bumi dan air dan .kekayaan alam yang terkandung didalamnya dikuasai oleh negara dan dipergunakan sebesar-besarnya untuk makmuran rakyat. Dalam UUD 1945 ditetapkan Indonesia sebagai sebuah negara kepulauan dengan panjang garis pantai mencapal $95.181 \mathrm{Km}$. Sebanyak 92 pulau kecil diantaranya merupakan pulau-pulau kecil terluar. Pulau-pulau tersebut kecil menyediakan sumber daya alam yang produktif diantaranya potensi perikanan. Oleh karna itu, untuk mengelola, dan mengamankan wilayah perairan yang demikian luas menjadi tanggung jawab yang besar dan berat.

Sebagai negara berkembang dengan populasi penduduk yang besar ditambah dengan struktur geografis yang dikelilingi oleh laut maka laut menjadi tumpuan sebagian besar penduduk Indonesia untuk memenuhi kebutuhan hidup terutama di daerah pesisir, seperti nelayan. Nelayan adalah kelompok masyarakat yang bermukim di kawasan pantai umumnya menggantungkan sumber kehidupan dan sektor kelautan dan perikanan. Selain itu, bagi negara kepulauan seperti indonesia, laut memiliki posisi yang strategis dan potensi yang luar biasa, di mana perairan indonesia adalah laut tenitorial baik perairan kepulauan maupun perairan penclalaman. Kemudian laut Indonesia juga sebagai perairan laut Zona Ekonomi Ekskulsif (ZEE), sesual pengumuman Pemerintah Republik Indonesia pada tanggal 31 Maret 1980, yang merupakan jaminan masa depan bangsa. ${ }^{2}$

Saat mi sangat marak terjadi penangkapan ikan secara illegal (illegal fishing) di wilayah perairan Indonesia dilakukan oleh nelayan lokal dan asing. Tidak sedikit kasus penangkapan nelayan-nelayan "nakal" dan luar negeri yang sengaja masuk ke kawasan perairan Indonesia untuk mengambil ikan maupun kekayaan laut lainnya.

\footnotetext{
${ }^{1}$ Marhaeni Ria Siombo, Hukum Perikanan Nasional dan Internasional, (Jakarta: PT Gramedia Pustaka Utama, 2010), hIm. 1.

${ }^{2}$ Frans.E.Lidkaja, Hukum Laut, (Bandung: Dzulkaidah, 1998), hlm. 39.
} 
Kapal-kapal patroli negara-negara luar mulai masuk ke perairan Indonesia yang seharusnya mereka tidak berhak atas $p$ erairan tersebut. ${ }^{3}$ Sumber daya ikan memang mempunyai daya pulih kembali walaupun hal tersebut bukan berarti tidak terbatas. Oleh karena itu, apabila pemanfaatannya dilakukan secara bertentangan dengan kaidahk aidah pengelolaan sumber daya ikan, misalnya eksplorasi berlebihan, penangkapan di luar zonasi yang telah ditentukan serta penggunaan alat yang yang dapat merusak sumber daya ikan dan/atau lingkungan. Semua hal tersebut dapat dikategorikan penangkapan ikan secara illegal yang tentunya akan berakibat terjadinya kepunahan dan kerusakan terhadap kelestarian lingkungan dan ekosistem disekitar laut. Untuk itu diperlukan kerjasama yang baik antara lembaga-lembaga penegak hukum di bidang perikanan, mengadakan koordinasi dan berkesinambungan dengan mengedepankan kepentingan bangsa dan negara. Sanksi yang dijatuhkan terhadap pelaku tindak pidana illegal fishing harus sesuai dengan kerugian yang diderita bangsa Indonesia. Setelah sekian lama dioperasionalkannya Undang-Undang Nomor 31 Tahun 2004 tentang Perikanan (selanjutnya disebut UU Perikanan), ternyata undang-undang mi belum mampu mengantisipasi perkembangan teknologi serta perkembangan kebutuhan hukum dalam rangka pengelolaan dan belum dapat menjawab permasalahan tersebut, baik dalam penegakan hukum maupun rumusan sanksi dan koordinasi antara para penegak hukum di bidang perikanan.

Untuk itu dikeluarkanlah Undang-Undang Nomor 45 Tahun 2009 tentang Perubahan atas Undang-Undang Nomor 31 Tahun 2004 tentang Perikanan (untuk selanjutnya disebut UU Perikanan). Salah satu faktor yang harus diperhatikan adalah dalam hal kewenangan melakukan penyidikan, karena banyaknya instansi yang mempunyal kewenangan untuk melakukan penyidikan akan menimbulkan stimulan untuk terjadinya kolusi, dan nepotisme sehingga proses penyelesaian perkara tindak pidana illegal fishing tidak akan mengakibatkan efek jera terhadap pelaku. Di wilayah Kepulauan Riau, Kalimantan, Sulawesi, Papua sering terjadi penangkapan ikan secara illegal yang dilakukan oleh nelayan lokal berbendera Indonesia dengan menggunakan bahan kimia berupa Pottasium chloride (suatu bahan kimia yang digunakan untuk mematikan ikan dan dapat membahayakan lingkungan sekitar) yang mana hal tersebut bertentangan dengan Pasal 8 ayat (1) Undang-Undang Nomor 31 Tahun 2004 menyatakan: "Setiap orang dilarang melakukan penangkapan ikan danlatau pembudidayaan ikan dengan menggunakan bahan kimia, bahan biologis, bahan peledak, alat dan/atau membahayakan kelestarian sumber daya

\footnotetext{
${ }^{3}$ Ayub Torry Satriyo Kusumo, Optimalisasi Pengelolaan dan Pemberdayaan Pulaupulau Terluar Dalam Rangka Mempertahankan Keutuhan Negara Kesatuan Republik Indonesia, Jurnal Dinamika Hukum, Volume 10, Nomor 3, September 2010, hlm. 321.
} 
ikan dan/atau lingkungannya di wilayah pengelolaan perikanan Republik Indonesia".

Pelanggaran atas pasal tersebut diancam dengan pidana Pasal 84 ayat (1) Undang-Undang Nomor 31 Tahun 2004. Perbuatan tersebut merupakan suatu tindak pidana. Selama mi keberadaan berbagai komoditas perikanan di perairan Indonesia yang cukup melimpah dan bernilai tinggi, mendorong peningkatan usaha penangkapan secara terus menerus dan tahun ketahun hingga munculnya berbagai teknik penangkapan yang tidak ramah lingkungan yang dilakukan oleh nelayan dan banyaknya prakti $\mathrm{k}$ illegal fishing.

Secara teontis, tindak pidana pencunian ikan (illegal fishing) adalah tindakàn menangkap ikan: ${ }^{4}$

1. Tidak dilengkapi Surat Izin Penangkapan Ikan (SIPI).

2. Menggunakan Surat Penangkapan Ikan (SPI) palsu.

3. Isi dokumen izin tidak sesuai dengan kapal dan jenis alat tangkapnya, menangkap jenis dan ukuran ikan yang dilarang.

Menurut UU Perikanan bahwa pencunian ikan (illegal fishing) adalah pencunian yang dilakukan karena menangkap ikan tanpa SIUP dan SIPI, menggunakan bahan peledak, bahan beracun, bahan berbahaya yang mengakibatkan kerusakan dan kepunahan sumber daya ikan. Tindakan illegal fishing tenjadi hampir di seluruh belahan dunia. Illegal

fishing merupakan kejahatan perikanan yang sudah teroganisasi secara matang, mulai di tingkat nasional sampai internasional.

Dewasa mi, tindakan illegal fishing telah berubah cara beroperasinya jika dibandingkan dengan cara beroperasi pada tahun 1990-an. Tindakan file gal fishing saat mi telah menjadi a highly sophisticated form of transnational organized crime, dengan ciri-ciri antara lain kontrol pergerakan kapal yang modern dan peralatan yang modern, termasuk tanki untuk mengisi bahan bakar di tengah laut. Menurut Giani dan Simpson, salah satu kesulitan untuk mencari data dan informasi yang akurat adalah fakta bahwa tindakan illegal fishing dikelola dan dijalankan dengan struktur korporasi yang tinggi tingkat kerahasiaannya serta jaringan bisnis yang kompleks yang sengaja menutup realitas sebenarnya yang terjadi. ${ }^{5}$

Penegakan hukum terhadap tindakan mi dinilai masih kurang memadai dikarenakan keterbatasan sarana dan prasarana. Meskipun demikian, pemermntah berupaya meminimalisir tindak pindana di bidang perikanan dengan melakukan deregulasi terhadap UndangUndang Nomor 9 Tahun 1985 diganti dengan UndangU ndang

${ }^{4}$ Lambok Silalahi, Tindak Pidana Pencurian Ikan (Illegal Fishing) diperairan Pantai Timur Sumatera Utara (Studi Kasus Keputusan PN Medan No. 1028/PID.B/2005/PN ME$D A N)$, Sekolah Pascasarjana, Universitas Sumatera Utara, Medan, 2006, hlm. 2.

${ }^{5}$ Giani. M dan W. Simpson, The changing Nature of High Sea Fishing, How Flag of Convinience Provide Cover for illegal, Unreported and Unregulated Fishing, (Australia: WWF dan Departement of Agriculture, Fisheries and Forestry, 2005), hlm. 84. 
Nomor 31 Tahun 2004 tentang Perikanan selanjutnya diubah dengan Undang Undang Nomor 45 Tahun 2009 tentang Perikanan. UndangUndang Nomor 45 Tahun 2009 mengamanatkan agar tindak pidana dibidang perikanan diselesaikan melalui jalur Pengadilan Penikanan. Masih banyak tindak pidana perikanan diselesaikan di Pengadilan Umum kanena penyidik dan jaksa masih menerapkan Kitab Undangundang Hukum Pidana (KUHP), seharusnya berlaku asas lex spesialis derogat lex generalis.

Bilamana dicermati UndangUndang Nomor 31 Tahun 2004 tentang Perikanan dan UndangUndang Nomor 45 Tahun 2009 tentang Perubahan atas UndangUndang Nomor 31 tentang Perikanan maka undang-undang tensebut bermuatan hukum administrasi. Hal mi dilihat dan ketentuan yang bersifat administratif, seperti Pasal 26 ayat (1) Undang-Undang Nomor 31 Tahun 2004 tentang Perikanan menyebutkan:

"Setiap orang yang melakukan usaha perikanan di bidang penangkapan, pembudidayaan, pengangkutan, pengolahan, dan pemasaran ikan di wilayah pengelolaan perikanan Republik Indonesia wajib memiliki SIUP (Surat Izin Usaha

Perikanan)". Pasal 26 ayat (2) menyebutkan: "Kewajiban memiliki SIUP sebagaimana hmaksud pada ayat (1), tidak berlaku bagi nelayan kecil dan/atau pembudidaya ikan kecil". Pasal 27 ayat (1) UndangUndang Nomor 31 Tahun 2004 menyebutkan: "Setiap rang yang memiWki dan/atau mengoperasikan kapal penangkap ikan berbendera Indonesia yang dipergunakan untuk meakukan penangkapan ikan di wilayah pengelolaan perikanan $\mathrm{Re}$ publik Indonesia dan/atau laut lepas wajib memiliki SIPI (Surat Izin Penangkapan Ikan)". Pasal 27 ayat (2) menyebutkan: "Setiap orang yang memiliki dan/atau mengoperasikan kapal penangkap ikan berbendera asing yang dipergunakan untuk melakukan penangkapan ikan di wilayah pengelolaan perikanan Republik Indonesia wajib memiliki SIPI (Surat Izin Penangkapan Ikan)". Pasal 28 ayat (1) menyebutkan: "Setiap orang yang memiliki dan latau mengoperasikan kapal pengangkut ikan di wilayah pengelolaan perikanan Republik Indonesia wajib memiliki SIKPI (Surat Izin Kapal Pengangkut lkan)".

Walaupun sudah ada aturan tersebut tidaklah setiap orang menaatinya, acapkali masih terjadi pelanggaran. Untuk penguatan dan penaatan berlakunya ketentuan yang bersifat administrasi tersebut maka dalam Undang-Undang Nomor 45 Tahun 2009 tentang Perubahan atas Undang-Undang Nomor 31 Tahun 2004 tentang Perikanan memuat ancaman pidana (penal policy). Penal policy merupakan usaha mewujudkan peraturan pidana yang baik, sesuai keadaan pada waktu tertentu dan untuk masa yang akan datang. ${ }^{6}$ Dalam UndangUndang Perikanan mi dimuat ketentuan pidana dalam Bab XV dan Pasal 84 sampai dengan Pasal 105. Adanya ancaman pidana kumulatif dalam undang-undang di bidang perikanan tidaklah berarti dengan

\footnotetext{
${ }^{6}$ Sudarto, Hukum dan Hukum Pidana, (Bandung: Alumni, 2010), hlm. 159.
} 
serta merta illegal fishing dapat dicegah dan dibasmi sampal tuntas ke akar-akarnya. Sulitnya penegakan hukum illeggal fishing setidaknya disebabkan oleh dua hal, yaitu tumpang tindihnya peraturan perundang-undangan yang berujung ketidakjelasan institusi yang berwenang dalam mengurus permasalahan illeggal fishing serta adanya konflik kepentingan diantara institusi tersebut. ${ }^{7}$ Persoalan mi tentu sangat menguntungkan pelaku illegal fishing. Kebijakan dalam penanggulangan illegal fishing yang menjadi landasan dalam kebijakan aplikasi maupun eksekusi maka UU Perikanan memuat regulasi atau formulasi baik mengenai hukum acana pidana maupun tindak pidana perikanan. ${ }^{8}$ Kementenian Kelautan dan Perikanan Republik Indonesia telah beberapa kali mengeksekusi kapal-kapal nelayan asing yang tertangkap dengan cara dibom dan ditenggelamkan, di mana aktivitas mi sangat diapresiasi oleh nelayan Indonesia, namun sangat diprotes oleh negaranegara yang kapalnya ditenggelamkan. ${ }^{9}$

Illegal fishing sangat merugikan negara maupun nelayan tradisional. Nelayan tradisional yang merupakan masyarakat Indonesia, sehingga masyarakat pesisir terse- but juga terkena imbas dan pencurian ikan. Selain itu, masyarakat lain yang menjadi konsumen juga ikut dirugikan karena tidak bisa menik mati hasil laut di negeni sendiri. Secara makro, mkan-ikan Indonesia dicuri lantas diolah dengan peralatan mumpuni sehingga meningkatkan harga jual di luar negeri. ${ }^{10}$ Perikanan laut diperkirakan menyumbang $78 \%$ dan total produksi perikanan tahun 2002 akan menjadi tumpuan

sektor mi. Kemiskinan yang berhadapan dengan kerapuhan lingkungan hidup, konflik dan dualisme ekonomi, serta tumpang tindih dan tidak berdayanya perangkat kebijakan, merupakan tantangan yang pada gilirannya akan berimbas pada keberlanjutan pertumbuhan sektor ini. ${ }^{11}$

Penelitian sejenis pernah dilakukan beberapa peneliti lain, seperti Abdul Qodir Jaelani dan Udiyo Basuki dengan judul Illegal Unreported and Unregulated (IUU) Fishing: Upaya Mencegah dan Memberantas Illegal Fishing dalam Membangun Poros Maritim Indonesia. Dalam penelitiannya dijelaskan bahwa pencegahan dan pemberantasan illegal fishing sebagai upaya membangun poros maritim adalah sebuah terobosan yang sudah la

\footnotetext{
${ }^{7}$ Akhmad Solihin, Politik Hukum Kelautan \& Perikanan, (Bandung: Nuansa Aulia, 2010), hlm. 44

${ }^{8}$ Gatot Supramono, Hukum Orang Asing di Indonesia, (Jakarta: Sinar Grafika, 2012), hlm. 108.

${ }_{9}$ Idrus Affandi, Kajian Hukum Terhadap Pencurian Ikan dilaut Berdasarkan UU Nomor 45 Tahun 2009 tentang Perubahan Atas UU Nomor 31 Tahun 2004 tentang Perikanan, Jurnal Lex Privatum, Volume V, Nomor 5, Juli 2017, hlm. 116. hIm. 210.

${ }^{10}$ Supriadi dan Alimudin, Hukum Perikanan Indonesia, (Jakarta: Sinar Grafika, 2011),

${ }^{11}$ https://www.facebook.com/budidaya.perairanunila/posts/364277950398199,diakses 25 Agustus 2017, pukul 10.00 Wib
} 
digaungkan. Hal mi bisa dilihat dan Indonesia yang telah mempunyai beberapa peraturan perundangundangan sebagai dasar hukum yang menjadi landasan pencegahan dan pemberantasan illegal fishing di Indonesia diantaranya UndangUndang Laut Tenitorial dan Lingkungan Maritim Tahun 1939 (Territorial Zee en Maritime Kringen Ordonantie, Stbl. 1939 No. 442), Undang-Undang Nomor 17 Tahun 1985 tentang Pengesahan United Nations Convention on the Law of the Sea (UNCLOS), UndangUndang Nomor 5 Tahun 1983 tentang Zona Ekonomi Ekslusif Indonesia, Undang-Undang Nomor 21 Tahun 1992 tentang Pelayaran, Undang-Undang Nomor 6 Tahun 1996 tentang Perairan Indonesia, Undang-Undang Nomor 31 Tahun 2004 ja. Undang-Undang Nomor 45 Tahun 2009 tentang Perikanan Undang-Undang Nomor 32 Tahun tentang Kelautan, Peraturan Menteri Kelautan dan Perikanan Republik Indonesia Nomor 2l PERMENKP/2015 tentang Larangan Penggunaan Alat Penangkapan Ikan Pukat Hela (trawis) dan Pukat Tarik(seine nets) di Wilayah Pengelolaan Perikanan Negara Republik Indonesia. Namun, kenyataannya di Indonesia masih banyak sekali kasus illegal fishing yang terjadi, hat $\mathrm{mi}$ bisa dilihat dan perkembangan Penenimaan Negara Bukan Pajak (PNBP) dan sektor KP mengalami fluktuasi. Pada 2005, berdasarkan data Kementerian Kelautan Perika- nan (KKP) PNBP sektor KP mencapai $\mathrm{Rp} 293,91$ miliar. Pada 2007, hanya mencapai $\mathrm{Rp} 134,63$ miliar atau menurun sekitar 54,2 persen. Selama 2007-2011, PNBP sektor $\mathrm{KP}$ mengalami peningkatan ratarata sebesar 12,1 persen. Faktor utarna yang mendukung adalah semakin intensifnya upaya penagihan atas tunggakan-tunggakan kewajiban PNBP pernegang izin kapal tangkap. Terjadinya fluktuasi disebabkan oleh beberapa hal diantaranya, adanya praktek pencurian ikan yang disebut Illegal, Unreported, Unregulated Fishing (IUU Fishing). Pada 2012, Badan Pemeriksa Keuangan (BPK) memperkirakan kerugman negara dan IUU Fishing sebesar Rp 300 Triliun. Dampak negatif yang lebih parah adalah kerusakan habitat dan ekosistem laut. Termasuk didalarnnya penangkapan ikan ilegal yang disertai perusakan terhadap lingkungan laut baik oleh born ikan, trawl, maupun menggunakan racun sianida. Kerusakan alam itu jika tidak segera diperbaiki rnaka ancaman kerugian lebih besar menghantui negara Indonesia yang akan bendampak besarjuga pada lingkungan bumi dan perubahan iklim global. ${ }^{12}$

Mawardi Khairi, pernah meneliti tentang Politik Hukum Pemerintah Dalam Penanganan Tindak Pidana Perikanan (Illegal Fishing) di Indonesia. Dalam penelitiannya dijelaskan politik hukurn pemerintah dalam bidang perikanan mengalami tiga kali perubahan, yaitu Undang-

\footnotetext{
${ }^{12}$ Abdul Qodir Jaelani dan Udiyo Basuki, Illegal Unreported and Unregulated (IUU) Fishing: Upaya Mencegah dan Memberantas Illegal Fishing dalam Membangun Poros Maritim Indonesia
} 
Undang Nomor 9 Tahun 1985, Undang-Undang Nomor 31 Tahun 2004 dan Undang-Undang Nomor 45 Tahun 2009 tentang Perikanan. Poiltik hukum pemenntah dalam bidang perikanan di era pemerintahan Jokowi-JK semakin menunjukkan bahwa illegal fishing adalah tindak pidana yang luar biasa sehingga membutuhkan keijasama penegakan hukum antar lembaga pemerintahan sehingga diterbitkanlah $\mathrm{Pe}-$ raturan Presiden Nomor 165 Tahun 2015 tentang Satuan Tugas Pemberantasan Tindak Pidana Illegal Fishing. ${ }^{13}$

Risnawati, pernah meneliti tentang perilaku menyimpang illegal fishing. Hash penelitian menggambarkan perilaku menyimpang (studi kasus illegal fishing di Taka Bonerate Kabupaten Kepulauan Selayar). Perilaku menyimpang, yaltu illegal fishing yang dimaksud adalah penangkapan ikan rnenggunakan bahan peledak born, sianida dan pembiusan. Perilaku nelayan terhadap ekosistem terumbu karang di Taka Bonerate Kabupaten Kepulauan Selayar dipengaruhi akibat rendahnya tingkat pendidikan sehingga pengetahuan tentang kerusakan ekosistem terumbu karangpun tidak dapat diketahui, penangkapan ikan dengan menggunkan bahan peledak juga berdampak terhadap keselamatan nyawa pelaku sendiri, ikan yang didapat tidak se- gar dan juga cepat busuk. Melakukan penangkapan ikan menggunakan bahan peledak dapat mempercepat banyaknya penghasilan sehingga masyarakatpun tetap untuk melakukan pemboman. ${ }^{14}$

Ignatius Yogi Widianto Se-

tyadi, pernah meneliti tentang upaya negara Indonesia dalam menangani masalah illegal fishing di Zona Ekonomi Eksklusif Indonesia. Hash! penelitiannya menjelaskan upaya Indonesia dalam menangani masalah illegal fishing di zona ekonomi eksklusif Indonesia, yaitu di ranah internasional, Indonesia turut aktif dalam hal pemberantasan IUU fishing. Salah satunya, yaitu dengan ikut dalam kerjasama internasional Regional Fisheris Management Organization (RFMO). Sementara di ranah nasional, Indonesia melalui Menteri Kelautan dan Perikanan telah mengeluarkan KEPMEN Nomor KEP/50/MEN/2012 tentang Rencana Aksi Nasional Pencegahan dan Penanggulangan Illegal, Ureported and Unregulated Fishing (IUU Fishing). Dalam hal penanganan kasus illegal fishing yang terjadi di wilayah perairan Indonesia, pemerintah Indonesia terlalu lunak dalam memproses pelaku pelanggaran. Hal inilah yang membuat negara-negara tetangga tidak menjadi segan terhadap Indonesia dan mengakibatkan kasus-kasus semacam mi selalu terjadh di wilayah pe

\footnotetext{
${ }^{13}$ Mawardi Khairi, Politik Hukum Pemerintah Dalam Penanganan Tindak Pidana Perikanan (Illegal Fishing) di Indonesia, Fiat Justisia Journal of Law, Volume 10, Issue 2 April-June 2016, hlm. 255.

${ }^{14}$ Risnawati, Perilaku Menyimpang Illegal Fishing, Jurnal Equilibrium Pendidikan Sosiologi, Volume IV, Nomor 1, Mei 2016, hlm. 38.
} 
rairan Indonesia. Upaya yang dilakukan Indonesia untuk menangani masalah illegal fishing kurang serius. Indonesia lebih mengedepankan isu-isu, seperti korupsi di birokrasi dibanding isu-isu mengenai illegal fishing. ${ }^{15}$

Bila ditelaah penelitian terdahulu tersebut berbeda dengan konten penelitian mi. Oleh karena itu, penelitian mi merupakan sesuatu yang baru atau berbeda dengan penelitian terdahulu (novelty). Adapun permasalahan dalam penelitian mi: Pertama, bagaimana tinjauan yuridis illegal fishing di Indonesia. Kedua, sanksi terhadap illegal fishing di Indonesia. Tujuan penelitian mi untuk menjelaskan tinjauan yuridis illegal fishing di Indonesia dan menjelaskan sanksi terhadap illegal fishing di Indonesia. Hasil yang diharapkan dan penelitian mi dapat menambah khasanah ilmu hukum di bidang perikanan dan bermanfaat bagi kalangan praktis.

\section{Metode Penelitian}

Jenis penelitian mi hukum normatif dengan metode pendekatan yuridis normatif. Penelitian hukum normatif merupakan suatu proses untuk menemukan aturan hukum, prinsipprinsip hukum maupun doktrindoktrin hukum guna menjawab isu hukum yang dihadapi. ${ }^{16}$

Sumber data yang digunakan dalam penelitian mi data se- kunder, terdiri atas bahan hukum primer, bahan hukum sekunder, dan bahan hukum tersier. ${ }^{17}$ Bahan hukum primer, yaitu bahan-bahan hukum yang mengikat. Bahan hukum primer dalam penelitian mi adalah Undang-Undang Nomor 31 Tahun 2004 tentang Perikanan dan perubahannya, yaitu Undang-Undang Nomor 45 Tahun 2009. Bahan hukum sekunder, yaitu bahan hukum yang memberikan penjelasan mengenai bahan hukum primer. Bahan hukum sekunder dalam penelitian mi terdiri atas buku, jurnal, artikel, dan literatur lamnnya yang berkaitan dengan permasalahan yang dibahas.

Teknik pengumpulan data yang digunakan dalam penelitian $\mathrm{mi}$ adalah studi kepustakaan, yaltu mengumpulkan literatur yang berhubungan dengan penelitian $\mathrm{mi}$, kemudian dianalisis dan diambil kesimpulannya.

Teknik analisis data yang digunakan dalam penelitian mi adalah analisis deskriptifk ualitatif dan analisis deskriptif evaluatif. Analisis deskriptif-kualitatif, yaitu penguraian data-data yang diperolehdalam suatu gambaran sistematis yang didasarkan pada teori dan pengertian hukum yang terdapat dalam ilmu hukum untuk mendapatkan kesimpulan yang signifikan dan ilmiah. Analisis deskriptif-evaluatif, yaitu analisis yang bertujuan untuk meng-

${ }^{15}$ Ignatius Yogi Widianto Setyadi, Upaya Negara Indonesia Dalam Menangani Masalah Illegal Fishing di Zona Ekonomi Eksklusif Indonesia, Skripsi, Fakultas Hukum, Universitas Atma Jaya Yogyakarta, 2014, hlm. 15.

${ }^{16}$ Peter Mahmud Marzuki, Penelitian Hukum, (Jakarta: Kencana, 2005), hlm. 35.

${ }^{17}$ Amirudin dan Zainal Asikin, Pengantar Metodologi Peneltian Hukum, (Jakarta: Raja Grafindo Persada, 2006), hlm. 35. 
gambarkan kondisi eksisting dan regulasi yang ada saat mi, kemudian di lakukan evaluasi berdasarkan kebutuhan melalui pendekatanpendekatan yang ditentukan guna menentukan langkah kebijakan yang tepat di masa yang akan datang.

\section{Pembahasan \\ Tinjauan Yuridis Illegal Fishing di Indonesia}

Indonesia sebagal negara kepulauan berada di jalur penghubung antara negara-negara belahan bumi selatan, utara, timur dan barat berpotensi mengalami gangguan kedaulatannya. Untuk mengantisipasinya maka diatur batas wilayahnya melalui hukum, baik dengan hukum nasional maupun hukum internasional. Perangkat hukum tapal batas Indonesia dengan negaranegara lain sampai saat mi belum final. Hal mi karena masih ada perbatasan yang menjadi persengketaan atau belum tuntas dirundingkan terkait perubahan geopolitik atau perubahan regional. Masalah perbatasan $\mathrm{ml}$ sangat penting bagi Indonesia karena sebagal negara kepulauan memiliki potensi kelautan dan permkanan.

Sektor kelautan dan perikananmendapat perhatian khusus ketika Presiden Abdurrahman Wahid menetapkan lahirnya Departemen Ekplorasi Laut dengan Keputusan Presiden Nomor 136 Tahun 1999, kemudian menjadi Departemen Kelautan dan Perikanan, saat mi dis ebut Kementerian Kelautan dan Perikanan (KKP). Pembentukan KKP didasari atas kesadaran bahwa sumber daya darat telah terkuras secara berlebihan dan terbatas sehingga dibutuhkan alternatif dan sumberdaya perikanan. KKP memiliki peran utama dalam pembuatan dan pelaksana kebijakank ebijakan di bidang perikanan yang diamanahkan Undang-Undang Perikanan.

Lahirnya Undang-Undang Perikanan (Undang-Undang Nomor 31 Tahun 2004) merupakan inisiatif dan Dewan Perwakilan Rakyat (DPR) untuk melahwkan suatu perubahan hukum di bidang Perikanan. Di samping itu, UndangUndang Penikanan merupakan solusi strategis agar sektor perikanan berperan besar dalam perekonomian dalam rangka mensejahterakan rakyat.

Penerapan Undang-Undang Penikanan ditindaklanjuti dengan Peraturan Pemerintah. Kebijakan tersebut mencakup berbagai aspek dalam penikanan, seperti ketentuan produksi keamanan pangan, ketentuan kapal dan alat tangkap, pencemaran perairan, dilengkapi dengan sanksi terkait illegal fishing. ${ }^{18}$

Pengertian illegal fishing tidak ada dicantumkan dalam peraturan perundangu ndangan Indonesia secara eksplisit. Pengertian illegal fishing merujuk pada pengertian yang dikeluarkan oleh International Plan of Action (IPOA) 2001 diprakarsai oleh Food Agriculture Organization (FAQ) dalam konteks imple-

\footnotetext{
${ }^{18} \mathrm{https}: / /$ pobersonaibaho.wordpress.com/2012/03/22/sejarah-singkat-kebijakanperikanan-indonesia-dari-masa-ke-masa/, diakes 25 Agustus 2017, pukul 10. 59 Wib.
} 
mentasi Code of Conduct for

Responsible Fisheries (CCRF) sebagal benikut. ${ }^{19}$

1. Activities conducted by national or foreign vessels in water under the jurisdiction of a state, without permission of that state, or in contravention of its laws and regulation. (Kegiatan penangkapan ikan yang dilakukan oleh suatu negara tertentu atau kapal asing di perairan yang bukan merupakan yurisdiksinya tanpa izin dan negara yang memiliki yunisdiksi atau kegiatan penangkapan ikan tersebut bertentangan dengan hukum dan peraturan negara itu).

2. Activities conducted by vessels flying the flag of states that are parties to a relevant Regional Fisheries Management Organization (RFMO) but operate in contravention of the conservation and management measures adopted by the organization and by which states are bound, or relevant pm visions of the applicable International Law. (Kegiatan penangkapan ikan yang dilakukan oleh kapal perikanan berbendera salah satu negara yang tergabung sebagai anggota organisasi pengelolaan perikanan regional, $R e$ gional Fisheries Manage- ment Organization (RFMQ), tetapi pengoperasian kapalkapalnya bertentangan dengan tindakan-tindakan konservasi dan pengelolaan perikanan yang telah diadopsi oleh RFMO. Negara RFMQ wajib mengikuti aturan yang ditetapkan itu atau aturan lain yang berkaitan dengan hukum internasional).

3. Activities in violation of national laws or international obligations, including those undertaken by cooperating stares to a relevant Regional Fisheries Management Organization (RFMO). (Kegiatan penangkapan ikan yang bertentangan dengan perundang-undangan suatu negara atau ketentuan internasional, termasuk aturanaturan yang ditetapkan negara anggota RFMO).

Dalam definisi internasional, kejahatan perikanan tidak hanya pencunian ikan (illegal fishing), namun juga penangkapan ikan yang tidak dilaporkan (unreported fishing), dan penangkapan ikan yang tidak diatur (unregulated fishing). Negara yang belum melaporkan status penikanannya, bisa dikategonikan telah melakukan kejahatan. Untuk itu, negara mesti melaporkan status perikanannya dengan data yang akurat sehinga dunia internasional dapat membantu Indonesia melalui tindakan yang tepat. ${ }^{20}$

${ }^{19}$ Section II International Plan of Action to Prevent, Deter and Eliminate Illegal, Unreported, and Unregulated Fishing, (Rome: Food And Agriculture Organization of The United Nations, 2001), hlm.

${ }^{20} \mathrm{http} / / /$ www.kkp.go.id/index.php/arsip/c/5419/Berantas-Kejahatan-Perikanan, diakses 23 Juni 2017, pukul 09.20 Wib. 
Dalam The Contemporaa'y English Indonesian Dictionaiy, "Illegal" artinya tidak sah, dilarang atau bertentangan dengan hukum. ${ }^{21}$

Sebagaimana disinggung pengertian illegal fishing tidak ada dicantumkan dalam peraturan perundang-undangan, tetapi ketentuan berikut jika dilanggar dapat dikategorikan illegal fishing, seperti: Pasal 4 Undang-Undang Nomor 31 Tahun 2004:

a. Setiap orang, baik warga negara Indonesia maupun warga negara asing dan badan hukum Indonesia maupun badan hukum asing, yang melakukan kegiatan perikanan di wilayah pengelolaan perikanan Republik Indonesia.

b. Setiap kapal perikanan berbendera Indonesia dan kapal perikanan berbendera asing, yang melakukan kegiatan perikanan di wilayah pengelolaan perikanan Republik Indonesia.

c. Setiap kapal perikanan berbendera Indonesia yang melakukan penangkapan ikan di luar wilayah pengelolaan perikanan Republik Indonesia.

d. Setiap kapal perikanan berbendera Indonesia yang melakukan penangkapan ikan, baik sendiri-sendiri maupun bersama-sama, dalam bentuk kerja sama dengan pihak asing.
Pasal 7 Undang-Undang Nomor 45 Tahun 2009:

Dalam rangka mendukung kebijakan pengelolaan sumber daya ikan, Menteri menetapkan:

a. Rencana pengelolaan perikanan;

b. Potensi dan alokasi sumber daya ikan di wilayah pengelolaan perikanan Negara Republik Indonesia;

c. Jumlah tangkapan yang diperbolehkan di wilayah pengelolaan perikanan Negara Republik Indonesia;

d. Potensi dan alokasi lahan pembudidayaan ikan di wilayah pengelolaan perikanan Negara Republik Indonesia;

e. Potensi dan alokasi induk serta benih ikan tertentu di wilayah pengelolaan perikanan Negara Republik Indonesia;

f. Jenis, jumlah, dan ukuran alat penangkapan ikan;

g. Jenis, jumlah, ukuran, dan penempatan alat bantu penangkapan ikan;

h. Daerah, jalur, dan waktu atau musim penangkapan ikan;

i. Persyaratan atau standar prosedur operasional penangkapan ikan;

j. Pelabuhan perikanan;

k. Sistem pemantauan kapal perikanan;

I. Jenis ikan baru yang akan dibudidayakan;

\footnotetext{
${ }^{21}$ Peter Salim, The Contemporary English Indonesian Dictionary, (Jakarta: Modern English Press, 2003), hlm. 65.
} 
m. Jenis ikan dan wilayah penebaran kembali serta penangkapan ikan berbasis budi daya;

n. Pembudidayaan ikan dan perlindungannya;

o. Pencegahan pencemaran dan kerusakan sumber daya ikan serta lingkungannya;

p. Rehabilitasi dan peningkatan sumber daya ikan serta lingkungannya;

q. Ukuran atau berat minimum jenis ikan yang boleh ditangkap;

r. Kawasan konservasi perairan;

s. Wabah dan wilayah wabah penyakit ikan;

t. Jenis ikan yang dilarang untuk diperdagangkan, dimasukkan, dan dikeluarkan ke dan dan wilayah Negara Republik Indonesia; dan

u. Jenis ikan yang dilindungi.

Pasal 9 Undang-Undang Nomor 45 Tahun 2009:

1) Setiap orang dilarang memiliki, menguasai, membawa, dan/atau menggunakan alat penangkapan dan/atau alat bantu penangkapan ikan yang mengganggu dan merusak keberlanjutan sumber daya ikan di kapal penangkap ikan di wilayah pengelolaan perikanan Negara Republik Indonesia.

2) Ketentuan mengenai alat penangkapan dan/atau alat bantu penangkapan ikan yang mengganggu dan merusak keberlanjutan sumber daya ikan sebagaimana dimaksud pada ayat (1) diatur dengan Peraturan Menteri.
Pasal 23 Undang-Undang Nomor 45 Tahun 2009

1) Setiap orang dilarang menggunakan bahan baku, bahan tambahan makanan, bahan penolong, dan/atau alat yang membahayakan kesehatan manusia dan/atau lingkungan dalam melaksanakan penanganan dan pengolahan ikan.

2) Pemerintah menetapkan bahan baku, bahan tambahan makanan, bahan penolong, dan/atau alat yang membahayakan kesehatan manusia dan/atau lingkungan sebagaimana dimaksud pada ayat (1).

3) Pemerintah melakukan sosialisasi bahan baku, bahan tambahan makanan, bahan penolong, dan/atau alat yang membahayakan kesehatan manusia danlatau lingkungan.

Masih banyak pasal-pasal lain yang secara khusus mengatur mengenai ketentuan teknis pelaksanaan penangkapan ikan di perairan Indonesia. Selain dalam Undang-Undang Perikanan juga diatur dalam peraturan perundang-undangan lainnya, yaitu:

1. Undang-Undang Nomor 27 Tahun 2007 tentang Pengelolaan Wilayah Pesisir dan Pulau-pulau Kecil serta aturan pelaksanaannya lainnya, sepenti Peraturan Pemenintah Nomor 54 Tahun 2005 tentang Usaha Perikanan.

2. Peraturan Pemerintah Nomor 60 Tahun 2007 tentang Konservasi Sumber Daya Ikan. 
3. Peraturan Pemerintah Nomor 30 Tahun 2008 tentang Penyelenggaraan Penelitian dan Pengembangan Perikanan.

4. Peratunan Menteni Kelautan dan Perikanan Nomor PER.13/MEN/2005 tentang Forum Koordinasi Penanganan Tindak Pidana di Bidang Penikanan.

5. Peraturan Menteri Kelautan dan Perikanan Nomor PER.14/MEN/2005 tentang Komisi Nasional Pengkajian Sumber Daya Ikan.

6. Peraturan Menteri Kelautan dan Perikanan Nomor PER. 1 5/MEN/2005 tentang Penangkapan Ikan dan/atau Pembudidaya Ikan di Wilayah Pengelolaan Penikanan Republik Indonesia yang Bukan Untuk Tujuan Komersial.

7. Peraturan Menteni Kelautan dan Perikanan Nomon PER.05/MEN/2008 tentang Usaha Penikanan Tangkap.

Peraturan perundang-undangan di atas secara tegas harus ditegakkan dalam rangka menjaga kedaulatan wilayah perairan. Setiap orang, badan dan negara asing wajib tunduk pada ketentuan hukum agar tidak terkena sanksi illegal fishing. Untuk memanfaatkan sumber daya penikanan agar tidak terkena sanksi illegal fishing maka dalam keadaan tertentu mesti dilengkapi pers-yaratan penizinan.

Penizinan merupakan salah satu cara untuk pengendalian penangkapan ikan. Pemberian izin dengan memperhatikan ketersediaan sumber daya ikan yang ada, memperhatikan aspek pelestarian lingkungan dan dampaknya terhadap ekosistem serta manfaatnya terhadap keberlanjutan sumber daya yang tersedia untuk masa depan bangsa.

Berikut mi beberapa jenis izin yang harus diperhatikan agar tidak tergolong kepada tindakan illegal fishing:

1. Surat Izin Usaha Perikanan (SIUP)

Pasal 26 Undang-Undang Nomor 31 Tahun 2004 menentukan: Setiap orang yang melakukan usaha perikanan di bidang penangkapan, pembudidayaan, pengangkutan, pengolahan, dan pemasaran ikan di wilayah pengelolaan perikanan Republik Indonesia wajib memiliki SIUP. Kewajiban memiliki SIUP tidak berlaku bagi nelayan kecil danlatau pembudidaya ikan kecil". Pasal 26 di atas secara tegas menyebutkan setiap usaha perikanan wajib memikili SIUP kecuali bagi nelayan kecil/pembudidaya ikan kecil.

2. Surat Izin Penangkapan Ikan (SIPI)

Pasal 27 Undang-undang Nomor 31 Tahun 2004 menentukan:

1) Setiap orang yang memiliki dan/atau mengoperasikan kapal penangkap ikan berbendera Indonesia yang dipergunakan untuk melakukan penangkapan ikan di wilayah pengelolaan perikanan Republik Indonesia dan/atau laut lepas wajib memiliki SIPI.

2) Setiap orang yang memiliki dan/atau mengoperasikan kapal penangkap ikan ber- 
bendera asing yang dipergunakan untuk melakukan penangkapan ikan di wilayah pengelolaan perikanan Republik Indonesia wajib memiliki SIPI.

3) SIPI sebagaimana dimaksud pada ayat (1) diterbitkan oleh Menteri.

4) Kapal penangkap ikan berbendera Indonesia yang melakukan penangkapan ikan di wilayah yurisdiksi negara lain harus terlebih dahulu mendapatkan persetujuan dan Pemerintah.

3. Surat Izin Kapal Pengangkut Ikan (SIKPI)

Surat izin kapal pengangkut ikan, yang selanjutnya disebut SIKPI adalah izin tertulis yang harus dimiliki setiap kapal perikanan untuk melakukan pengangkutan ikan. Pasal 28 Undang-undang Nomor 31 Tahun 2004 menentukan:

1) Setiap orang yang memiliki dan/atau mengoperasikan kapal pengangkut ikan di wilayah pengelolaan perikanan Republik Indonesia wajib memiliki SIKPI.

2) SIKPI sebagaimana dimaksud pada ayat (1) diterbitkan oleh Menteri.

Dalam penerbitan izin sangat diperlukan disiplin yang ketat oleh para pihak yang terkait. Saat mi kegiatan penangkapan ikan di Indonesia telah menghadapi kondisi yang kritis. Ekplorasi dan ekploitasi tanpa batas dapat merugikan bangsa Indonesia. Untuk itu perlu pembatasan dan konsistensi dalam pelarangan penangkapan ikan yang bertujuan untuk kesejahteraan manusia di kemudian han.

\section{Sanksi Terhadap Illegal Fishing di Indonesia}

Banyak faktor yang tenidentifikasi penyebab terjadmnya illegal fishing di perairan Indonesia, yaitu: ${ }^{22}$

1. Luasnya potensi laut yanq belum dikelola;

2. Peluang bisnis ikan yang menggiurkan;

3. Kelemahan penegakan hukum;

4. Mentalitas aparat;

5. Faktor perundang undangan.

Reformasi hukum perikanan di Indonesia adalah dengan diundangkannya Undang-Undang Nomor 31 Tahun 2004 kemudian diubah dengan Undang-Undang Nomor 45 tahun 2009 tentang Perikanan. Undang-undang $\mathrm{mi}$ amatlah penting mengingat luas perairan Indonesia mendekati 6 juta kilometer persegi mencakup perairan kedaulatan dan yuridiksi nasional memerlukan penegakan hukum dan pengamanan laut dan gangguan dan upaya pihak asing. ${ }^{23}$

Sanksi terhadap illegal fishing diatur dalam Undang-Undang Perikanan terdapat dalam beberapa pasal diantaranya Pasal 84 sampai dengan-

\footnotetext{
${ }^{22}$ https://nurhasanblogger.wordpress.com/2015/12/17/penyelesaian-illegal-fishingberdasarkan-undang-undang-nomor-45-tahun-2009-2/, diakses 25 Agustus 2017, pukul 12.30 Wib.

${ }^{23}$ ibid.
} 
Pasal 104. Pasal 84 menyatakan:

1) Setiap orang yang dengan sengaja di wilayah pengelolaan perikanan Republik Indonesia melakukan penangkapan ikan dan/atau pembudidayaan ikan dengan menggunakan bahan kimia, bahan biologis, bahan peledak, alat dan/atau cara, dan/atau bangunan yang dapat merugikan dan/atau membahayakan kelestanian sumber daya ikan dan/atau lingkungannya sebagaimana dimaksud dalam Pasal 8 ayat (1), dipidana dengan pidana penjara paling lama 6 (enam) tahun dan denda paling banyak $\mathrm{Rp}$ 200.000.000,00 (satu miliar dua ratus juta rupiah).

2) Nakhoda atau pemimpmn kapal perikanan, ahli penangkapan ikan, dan anak buah kapal yang dengan sengaja di wilayah pengelolaan perikanan Republik Indonesia melakukan penangkapan ikan dengan menggunakan bahan kimia, bahan biologis, bahan peledak, alat dan/atau cara, dan/atau bangunan yang dapat merugikan dan/atau membahayakan kelestarian sumber daya ikan dan/atau lingkungannya sebagaimana dimaksud dalam Pasal 8 ayat dipidana dengan pidana penjara paling lama 10 (sepuluh) tahun dan denda paling banyak $\mathrm{Rp}$ 200.000.000,00 (satu miliar dua ratus juta rupiah).
3) Pemilik kapal perikanan, pemilik perusahaan penikanan, penanggung jawab perusahaan perikanan, dan /atau operator kapal penikanan yang dengan sengaja di wilayah pengelolaan perikanan Republik Indonesia melakukan usaha penangkapan ikan dengan menggunakan bahan kimia, bahan biologis, bahan peledak, alat dan/ atau cara, dan/atau bangunan yang dapat merugikan dan/atau membahayakan kelestanian sumber daya ikan dan/atau lingkungannya sebagaimana dimaksud dalam Pasal 8 ayat (3), dipidana dengan pidana penjara paling lama 10 (sepuluh) tahun dan denda paling banyak Rp 2.000.000.000,00 (dua miliar rupiah.

4) Pemilik perusahaan pembudidayaan ikan, kuasa pemilik perusahaan pembudidayaan ikan, dan/ atau penanggung jawab perusahaan pembudidayaan ikan yang dengan sengaja melakukan usaha pembudidayaan ikan di wilayah pengelolaan penikanan Republik Indonesia menggunakan bahan kimia, bahan biologis, bahan peledak, danlatau cara, dan/atau bangunan yang dapat merugikan dan/atau membahayakan kelestanian sumber daya ikan dan/atau lingkungannya sebagaimana dimaksud dalam Pasal 8 ayat (4), dipidana dengan pidana 
penjara paling lama 10 (sepuluh) tahun dan denda paling banyak $R p$ 2.000.000.000, (dua miliar rupiah).

Pasal 85 pada Undang-Undang Nomor 31 Tahun 2004 mengalami perubahan, yaitu:

"Setiap orang yang dengan sengaja di wilayah pengelolaan perikanan Republik Indonesia memili$\mathrm{ki}$, menguasal, membawa, dan/atau menggu nakan alat penangkapan ikan dan/atau alat bantu penangkapan ikan yang berada di kapal penangkap ikan yang tidak sesual dengan ukuran yang ditetapkan, alat penangkapan ikan yang tidak sesuai dengan persyaratan, atau standar yang ditetapkan untuk tipe alat tertentu dan/atau alat penangkapan ikan yang dilarang sebagaimana dimaksud dalam Pasal 9, dipidana dengan pidana penjara paling lama 5 (lima) tahun dan denda paling banyak Rp 2.000.000.000,00 (dua miliar rupiah)"

Dalam Undang-Undang Nomor 45 Tahun 2009 berubah menjadi:

"Setiap orang yang dengan sengaja memiliki, menguasai, membawa, dan/atau menggunakan alat penangkap ikan dan/atau alat bantu penangkapan ikan yang mengganggu dan merusak keberlanjutan sumber daya ikan di kapal penangkap ikan di wilayah pengelolaan perikanan Negara Republik Indonesia sebagaimana dimaksud dalam Pasal 9 dipidana dengan pidana penjara paling ama 5 (lima) tahun dan denda paling banyak $R p$ 2.000.000.000,00 (dua miliar rupiah)".

Pasal 85 Undang-Undang Nomor 45 Tahun 2009, terlihat bahwa tidak hanya aktivitas penangkapan yang menyalahi aturan yang dihukum, melainkan juga dan aktivitas yang mengakibatkan rusaknya keberlanjutan sumber daya ikan di wilayah pengelolaan perikanan Negara Republik Indonesia.

Ketentuan Pasal 93 UndangUndang Nomor 31 Tahun 2004 juga mengalami perubahan dalam Undang-undang Nomor 45 tahun 2009 dengan rumusan:

1) Setiap orang yang memiliki dan/atau mengoperasikan kapal penangkap ikan berbendera Indonesia melakukan penangkapan ikan di wilayah pengelolaan perikanan Negara Republik Indonesia dan/atau di laut lepas, yang tidak memiliki SIPI sebagaimana dimaksud dalam Pasal 27 ayat (1), dipidana dengan pidana penjara paling ama 6 (enam) tahun dan denda paling banyak Rp 2.000.000.000,00 (dua miliar rupiah).

2) Setiap orang yang memiliki dan/atau mengoperasikan kapal penangkap ikan berbendera asing melakukan penangkapan ikan di ZEE yang tidak memiliki SIPI sebagaimana dimaksud dalam Pasal 27 ayat (2), dipidana dengan pidana penjara paling ama 6 (enam) tahun dan denda paling banyak Rp 20.000.000.000,00 (dua puluh miliar rupiah).

3) Setiap orang yang mengoperasikan kapal penangkap ikan berbendera Indonesia di wilayah pengelolaan perikanan Negara Republik In- 
donesia, yang tidak membawa SIPI asH sebagaimana dimaksud dalam Pasal 27 ayat (3), dipidana dengan pidana penjara paling lama 6 (enam) tahun dan denda paling banyak $\mathrm{Rp}$ 2.000.000.000,00 (dua miliar rupiah).

4) Setiap orang yang mengoperasikan kapal penangkap ikan berbendera asing di ZEE, yang tidak membawa SIPI ash sebagaimana dimaksud dalam Pasal 27 ayat (3), dipidana dengan pidana penjara paling lama 6 (enam) tahun dan denda paling banyak $\mathrm{Rp}$ 20.000.000.000,00 (dua puluh mihiar rupiah).

Terdapat penambahan ayat (3) dan 4 dalam pasal yang baru mengenai prosedur teknis penangkapan ikan dengan membawa Surat Izin Penangkapan Ikan (SIPI) di wilayah pengelolaan perikanan Repubhik Indonesia. Tujuan penghukuman untuk pencegahan maka besarnya hukuman harus sedemikian rupa tidak boleh kurang atau lebih dan batas yang dipenlukan. Dengan demikian, maka terdapat prinsip keadilan dalam menjatuhkan hukuman. ${ }^{24}$

Berbagai upaya telah dilakukan oleh Pemerintah dalam rangka pencegahan dan penindakan illegal fishing selanjutnya sangat diperlu- kan kerjasama dan koordinasi diantara seluruh unsur terkait sehingga dapat mengamankan dan melindungi sumber daya alam untuk kepentingan nasional.

\section{Simpulan}

1. Undang-Undang Perikanan telah merumuskan banyak hal balk mengenal pencegahan, pengawasan, pemberdayaan dan penindakan terhadap pelaku sektor perikanan balk nelayan nasional maupun nelayan asing. Begitu juga dan jenis alat tangkapnya yaltu nelayan tradisional sampai nelayan modern.

2. Sanksi dalam UndangUndang Perikanan terbaru lebih berat dibandingkan undang-undang sebelumnya. Dengan sanksi yang lebih beratpun belum memberikan efek jera kepada pelaku illegal fishing. Sanksi 6 tahun penjara bagi pelaku penangkapan ikan tanpa SIPI, sanksi 7 tahun bagi pemalsuan SIUP, SIP,, SIK$\mathrm{PI}$. Denda paling banyak Rp 20.000.000.000. Namun, sayangnya undangu ndang tidak memuat rumusan sanksi minimum sehingga hal mi menjadi celah hukum.

\footnotetext{
${ }^{24}$ Fitri Wahyuni, Sanksi Bagi Penista Agama Dalam Perspektif Hukum Pidana Indonesia dan Hukum Pidana Islam, Jurnal Das Sollen, Volume 1, Nomor 1, Juni 2017, hlm. 69.
} 


\section{Referensi}

Abdul Qodir Jaelani dan Udiyo Basuki. Illegal Unreported and Unregulated (IUU) Fishing: Upaya Mencegah dan Memberantas Illegal Fishing dalam Membangun Poros Maritim Indonesia. Jurnal Supremasi Hukum. Volume 3. Nomor 1. Juni 2014.

Amirudin dan Zainal Asikin. 2006.

Pengantar Metodologi Peneltian Hukum. Jakarta: Raja Grafindo Persada.

Akhmad Solihin. 2010. Politik Hukum Kelautan \& Perikanan. Bandung: Nuansa Aulia.

Ayub Torry Satriyo Kusumo. Optimalisasi Pengelolaan dan Pemberdayaan Pulau-pulau Terluar Dalam Rangka Mempertahankan Keutuhan Negara Kesatuan Republik Indonesia. Jurnal Dinamika Hukum. Volume 10. Nomor 3 September 2010.

Fitri Wahyuni. Sanksi Bagi Penista Agama Dalam Perspektif Hukum Pidana Indonesia dan Hukum Pidana Islam. Jurnal Das Sollen. Volume 1. Nomor 1. Juni 2017.

Frans.E.Lidkaja. 1998. Hukum Laut. Bandung: Dzulkaidah.

Gatot Supramono. 2012. Hukum Orang Asing di Indonesia. Jakarta: Sinar Grafika.
Giani. M dan W. Simpson. 2004. The changing Nature of High Sea Fishing, How Flag of Convinience Provide Cover for illegal, Unreported and Unregulated Fishing. Australia: WWF dan Departement of Agriculture Fisheries and Forestry.

Idrus Affandi. Kajian Hukum Terhadap Pencurian Ikan dilaut Berdasarkan UU Nomor 45 Tahun 2009 tentang Perubahan Atas UU Nomor 31 Tahun 2004 tentang Perikanan. Jurnal Lex Privatum. Volume V. Nomor 5. Juli 2017.

Ignatius Yogi Widianto Setyadi. Upaya Negara Indonesia Dalam Menangani Masalah Illegal Fishing di Zona Ekonomi Eksklusif Indonesia. Skripsi. Fakultas Hukum. Universitas Atma Jaya Yogyakarta. 2014.

Lambok Silalahi. Tindak Pidana Pencurian Ikan (Illegal Fishing) diperairan Pantai Timur Sumatera Utara (Studi Kasus Keputusan PN Medan No. 1028/PID.B/2005/PN MEDAN). Sekolah Pascasarjana. Universitas Sumatera Utara. Medan. 2006.

Marhaeni Ria Siombo. 2010. Hukum Perikanan Nasional dan Internasional.Jakarta: PT Gramedia Pustaka Utama. 
Mawardi Khairi. Politik Hukum Pemerintah Dalam Penanganan Tindak Pidana Perikanan (Illegal Fishing) di Indonesia. Fiat Justisia Journal of Law. Volume 1. Issue 2 AprilJune 2016.

Peter Salim. 2003. The Contemporary English Indonesian Dictionary. Jakarta: Modern English Press.

Peter Mahmud Marzuki. 2005. Penelitian Hukum. Jakarta: Kencana.
Risnawati. Perilaku Menyimpang Ilegal Fishing. Jurnal Equilibrium Pendidikan Sosiologi. Volume IV. Nomor 1. Mei 2016.

Sudarto. 2010. Hukum dan Hukum Pidana. Bandung: Alumni.

Supriadi dan Alimudin. 2010. Hukum Perikanan Indonesia. Jakarta: Sinar Grafika. 